\title{
Experiencing Time in the Early English East India Company
}

\author{
Mark R. F. Williams \\ Department of History, Cardiff University, Cardiff, UK \\ Email: williamsm64@cardiff.ac.uk
}

\begin{abstract}
The structuring of time in the early modern period has traditionally been associated with a broad, European-led shift towards 'accuracy', and with it connotations of 'modernity'. Yet, a fuller examination of the temporal world of early modern merchants challenges such a teleology. Taking as its focus the English East India Company (EIC), this article situates concerns for accuracy in the management of time (and with it profit) within a broader spectrum of temporal influences, including seasonal, indigenous, and embodied time. It draws upon the experiences of the merchant Isaac Lawrence (1639-79), whose trade began around the Mediterranean Sea but ended in the service of the EIC in Persia. Like many of his contemporaries in the Company, Lawrence died relatively young and in obscure circumstances; however, the survival of his personal papers through his brother William Lawrence affords vital insights into how time was observed, measured, and felt within mobile early modern lives. Read alongside Company records, Lawrence's experience makes clear the necessity of reading subjective temporalities into historical understandings of time within global frameworks.
\end{abstract}

I have by a worthy Gentleman my friend directed to Mr Wm Bowtell one small round Box to be conveyed to you; [it] conteines my Watch, the spring of it being broake is become unserviceable to mee at present so desire you to keep it by you untill my returne, or againe to send it me as I shall advise you of my set[t]lem[en]t for a few yeares until a change of fortune at home.

\section{Isaac Lawrence to William Lawrence, from Fort St George [Madras/} Chennai], 30 November $1677^{1}$

At some point in the course of his long voyage to India in search of employment with the East India Company (EIC), Isaac Lawrence's watch broke. This

\footnotetext{
${ }^{1}$ British Library India Office Records (IOR), Mss Eur E387, letters of Isaac Lawrence (LP), vol. A, fo. $23 \mathrm{v}$.

(C) The Author(s), 2022. Published by Cambridge University Press. This is an Open Access article, distributed under the terms of the Creative Commons Attribution licence (http://creativecommons.org/licenses/by/4.0/), which permits unrestricted re-use, distribution and reproduction, provided the original article is properly cited.
} 
was no small loss. For Lawrence's contemporary, Samuel Pepys, such portable timepieces afforded not only a means of structuring his day, permitting him to note exact appointments at regular times in the course of his ambitious social schedule, but also the measure of time lost to transit and disorganization. ${ }^{2}$ For Lawrence, as with Pepys, such a timepiece would have conferred a certain measure of social status, both as an expensive object and as a signifier that his time was so valuable as to be measured precisely and recorded as such. ${ }^{3}$ As he entered into the service of the East India Company, the watch might have permitted Lawrence to gauge inefficiencies in his trade or to adjust his daily routine to the temporal rhythms of his new surroundings: the familiar 'ticks' and 'tocks' of European time in foreign places. Instead, the now 'unserviceable' shell of the watch was sent to Isaac's older brother William back in England, with the instruction to either have it repaired and swiftly returned once Isaac had settled in India, or to await his return to England. ${ }^{4}$

With the loss of the watch, it would seem that the precision that Jacques Le Goff identified as one of the markers of the 'orderly conduct of business' among merchants like Isaac Lawrence in the transition from medieval 'church time' to modern 'merchant time' had perished. ${ }^{5}$ Yet, time neither stopped nor ceased to be a central feature of Isaac Lawrence's life simply because he had lost one means of gauging it. Even at the time of Isaac's departure from England in 1675, his brother William was also responding to a perceived loss of time and a growing sense of distance between them. To navigate this, William attempted to close such gaps through the sharing of time: he began keeping a diary of his year at home to send to Isaac abroad. His purpose in doing so was explained to Isaac early in the diary:

That the severe Decrees of Heaven have again contradicted the Requests of Nature and not only designed another Separation, but remov'd you into a more distant and a more dangerous Clime, is a misfortune...My last letter show'd my owne melancholy, but by this I will endeavour to divert yours, and give you a lipid account of thinges and persons. ${ }^{6}$

The diary as it subsequently unfolds blends numerous early modern genres in the pursuit of 'diverting melancholy'. It is structured according to monthly entries through much of the following year, running March through October. In each of these months, William takes note of local and national affairs with both scathing criticism and scurrilous detail as he moves between the family home of Shurdington in Gloucestershire and his business in London,

\footnotetext{
${ }^{2}$ Stuart Sherman, Telling time: clocks, diaries, and English diurnal form, 1660-1785 (Chicago, IL, 1996), ch. 3.

${ }^{3}$ On Pepys's atypical use of clock-time, see Paul Glennie and Nigel Thrift, Shaping the day: a history of timekeeping in England and Wales, 1300-1800 (Oxford, 2009), pp. 261-4.

${ }^{4}$ Isaac Lawrence (IL) to William Lawrence (WL), 30 Nov. 1677, IOR, LP, vol. A, fo. 23v.

${ }^{5}$ Jacques Le Goff, 'Merchant's time and church's time in the middle ages', in Time, work \& culture in the middle ages, trans. Arthur Goldhammer (Chicago, IL, 1980), p. 35.

${ }^{6}$ William Lawrence, The diary of William Lawrence, covering periods between 1662 and 1681, ed. G. E. Aylmer (Beaminster, 1961), p. 1.
} 
fusing national scandal with the intimate details of family life. For William, the clock itself had become a metaphor for his brother's absence abroad, lamenting to Isaac that it

fixeth my Soule and weights it down with many melancholy thoughts, methinkes its motion is like that of a Clock;...like a Clock it measures minutes, houres and days; and is constantly moving in a Circle of warme and repeated wishes that the constitution of your Health may be secure and unshaken; that the time of your Absence may weare away and expire. ${ }^{7}$

These references to the Lawrence brothers' two timepieces - one broken, imprecise watch awaiting return; the other, a 'clock' measuring absence in 'minutes, houres and days', wearing time away in the process - ask us to consider the experience of time 'on the move' in the early modern period. Certainly, the precision embodied in Isaac's shattered watch had risen in importance for merchants like him, whose successes and failures were shaped by what Le Goff called 'the price of time'. Yet - as Isaac and William clearly understood-precision was not the only means by which time was given value in these circumstances. Le Goff's own formulation of 'merchant time' in the late medieval period was attuned not only to the advent of mechanical precision but also the 'conquest of time and space'. The duration of a trip, discontinuities in activity, and the pliability of time in the creation of profit were the buttresses of these new understandings of time. ${ }^{8}$ These were not simply terms of measured precision, but the experience of time in qualitative terms of investment, risk, and - as the Lawrences clearly saw it - a life well spent. ${ }^{9}$ As Stefan Hanß has argued, the 'fetishization' of accuracy in the study of time has come at the expense of comprehending the multiple, overlapping, and often competing forms which time could take by the latter half of the seventeenth century. ${ }^{10}$ Where Isaac's shattered watch entices us to think about aspirations towards (and the challenges of) efficiency and precision, William's 'clock' demands that we consider not only the subjective experience of time as felt by the brothers, but also the many ways in which global movement created novel and challenging experiences of time: time separated from familiar rituals and symbols rooted in known geographies, and instead shaped by encounter, disorientation, and dislocation. ${ }^{11}$ This required new settings and understandings of time as an essential facet of mobility and a key site in the (re)orientation of mobile lives. In this sense, global movement was as much a temporal experience as a spatial one. The example of the Lawrence brothers

\footnotetext{
${ }^{7}$ Ibid., p. 22.

${ }^{8}$ Le Goff, 'Merchant's time', pp. 35-7.

${ }^{9}$ Emily C. Nacol, An age of risk: politics and economy in early modern Britain (Princeton, NJ, 2017); Sarah Goldsmith, Masculinity and danger on the eighteenth-century Grand Tour (London, 2020), pp. 37-73.

${ }^{10}$ Stefan Hanß, 'The fetish of accuracy: perspectives on early modern time(s)', Past \& Present, 243 (2019), p. 277.

${ }^{11}$ Suggested in Matthew S. Champion, The fullness of time: temporalities of the fifteenth-century Low Countries (Chicago, IL, 2017), p. 203.
} 
reveals 'everyday and global contexts' which could reshape not only how time was perceived, measured, and accounted for, but also how it was felt, projected, or even lost as people moved across these expanding spaces. ${ }^{12}$

Central to this analysis will be the role of the East India Company in which Isaac Lawrence first sought and then found employment: the aspirant mercantile life his watch might be said to embody. As I will show, working for the EIC not only framed Lawrence's personal ambitions within a global geography, but also became an important organizing structure around which time was comprehended and acted upon. Considering the predominance of merchants in the driving of such narratives of early capital, modernity, and even their conspicuous consumption of timepieces, it is remarkable that the East India Company has never been considered as an entity both shaped by and capable of shaping time across its global operations: 'merchant time' at a global scale. ${ }^{13}$ The history of temporalities remains largely focused on static entities within defined geographies, mapping the 'textures' of time within demarcated boundaries with entrenched symbols and established rituals. ${ }^{14}$ Time 'in motion' has been discussed with regard to maritime spaces, where regularization and measurement have been read alongside the importance of experience and the 'feel' of natural rhythms at sea; however, such consideration of movement often stops at the shoreline. ${ }^{15}$ Only with the advent of 'the modern' does time seem to emerge as something capable of moving and transcending wider spatial boundaries: most often as a harbinger of modernity or imperial imposition, sometimes as the product of negotiation. ${ }^{16}$

Yet, as I will show, Isaac Lawrence's life within the East India Company's trading world was fundamentally shaped by the Company's enduring concern for - and, as often, a failure to achieve - the profitable structuring of time in the context of constant movement. Formative historians of the East India Company such as K. N. Chaudhuri were clearly attuned to its relationship with time, highlighting institutional imperatives to regularize shipments, impose routine, and manage conflict according to profit. ${ }^{17}$ In contrast, the post-colonial study of both the EIC and its competitors has sought to centre the development (and then dismantling) of unifying systems of measurement, information-gathering, and observation within burgeoning imperial mechanisms of control, responsive to but also deeply connected to relationships

\footnotetext{
${ }^{12}$ Ibid., pp. 282-4.

${ }^{13}$ For exceptions, see Glennie and Thrift, Shaping the day, ch. 8; William M. Reddy, 'The Eurasian origins of empty time and space: modernity as temporality reconsidered', History and Theory, 55 (2016), pp. 325-56.

${ }^{14}$ Champion, The fullness of time, passim; E. P. Thompson, 'Time, work-discipline, and industrial capitalism', Past \& Present, 38 (1967), pp. 56-97.

${ }^{15}$ Glennie and Thrift, Shaping the day, pp. 281-5.

${ }^{16}$ Most notably in Vanessa Ogle, The global transformation of time, 1870-1950 (Harvard, MA, 2015); Giordano Nanni, The colonisation of time: ritual, routine and resistance in the British empire (Manchester, 2012); Stephen Kern, The culture of time and space, 1880-1918 (2nd edn, Harvard, MA, 2003).

${ }^{17} \mathrm{~K} . \mathrm{N}$. Chaudhuri, The English East India Company: the study of an early joint-stock company, 16001640 (London, 1999).
} 
beyond the Company. ${ }^{18}$ Ann Laura Stoler's work on the later archives of the Dutch East India Company (Vereenigde Oostinsche Compagnie or VOC), for instance, has posed valuable questions about how institutional archives might be read 'along the grain' to understand them as sites of ever-deepening imperial anxiety within these 'never-stable' enterprises. ${ }^{19}$ The relationship of the EIC to time as reflected in the archive is similarly engrained with anxieties about the function and control of time within and beyond its boundaries. Examination of Isaac Lawrence's experience 'on the ground' as an EIC servant through a combined reading of his personal records and those of the Company will therefore afford valuable insights into a mobile life simultaneously within and outside of 'Company time': not only along or against the grain of these archives, but in accordance with their varied synchronizations.

What, then, of William's 'clock'? Attuned to the rigours of distance, health, and absence rather than the precise passing of time, it demands attention to alternative temporalities and their global resonances. The wider world in which the East India Company operated was not simply an inert backdrop against which it acted at will: it, too, set the clocks by which merchants and families like the Lawrences operated. ${ }^{20}$ Rather, the complex interactions of the Company and its servants with not only the diverse societies they encountered, but also the landscapes, weather systems, physical demands, indigenous temporalities, and quotidian rhythms such travels entailed, made time much more than an exercise in Company selfregulation and observation. ${ }^{21}$ Often comprised of 'time-expired servants clamouring to be sent home', its operations were framed by the physical limits of bodies situated in ever-changing environs. ${ }^{22}$ This 'embodied time' located in the physical experience of servants like Lawrence - sustaining and prolonging life (and with it, profit); dynamics of youth and age; mortality - was inextricably entwined with the landscapes which sustained them and which they traversed. ${ }^{23}$ Emotional states of

${ }^{18}$ Miles Ogborn, Indian ink: script and print in the making of the English East India Company (London, 2007); Anna Winterbottom, Hybrid knowledge in the early East India Company world (Basingstoke, 2016); Adrien Delmas, Les voyages de l'écrit: culture écrite et expansion européenne à l'époque modern: essais sur la Compagnie Hollandaise des Indes Orientales (Paris, 2013).

${ }^{19}$ Ann Laura Stoler, Along the archival grain: epistemic anxieties and colonial common sense (Princeton, NJ, 2009), p. 19.

${ }^{20}$ David Veevers, The origins of the British empire in Asia, 1600-1750 (Cambridge, 2020).

${ }^{21}$ There is a rich literature on cultural encounter: see, for instance, Susan Broomhall, "'Quite indifferent to these things": the role of emotions and conversion in the Dutch East India Company's interactions with the south lands', Journal of Religious History, 39 (2015), pp. 1-21; Amrita Sen, 'Searching for the Indian in the English East India Company Archives: the case of Jadow the Broker and early seventeenth-century Anglo-Mughal trade', Journal for Early Modern Cultural Studies (JEMCS), 17 (2017), pp. 37-58; Sanjay Subrahmanyam, Europe's India: words, people, empires, 1500-1800 (Cambridge, 2017).

${ }^{22}$ A. T. Grove, 'St Helena as a microcosm of the East India Company world', in Vinita Damodaran, Anna Winterbottom, and Alan Lester, eds., The East India Company and the natural world (Basingstoke, 2015), p. 252.

${ }^{23}$ For 'embodied time', see Merry E. Wiesner-Hanks, ed., Gendered temporalities in the early modern world (Amsterdam, 2018), esp. pt 3; Marc Wittman, 'Embodied time: the experience of time, the body, and the self, in Valtteri Arstila and Dan Lloyd, eds., Subjective time: the philosophy, psychology, and neuroscience of temporality (Cambridge, MA, 2014), pp. 507-23. 
boredom, anxiety, listlessness - the 'melancholy' William anticipated in his brother-depended on opportunities afforded by seasons of trade and ritual embedded in local custom which predated the EIC's arrival and were unfamiliar to Lawrence. Success and failure in these environments meant first understanding and then moving with the temporal practices of local merchants, the calendars which drove their activity, and the natural rhythms which facilitated or prohibited it. ${ }^{24}$ This meant that the sense of time communicated between and experienced by the two brothers was as much shaped by tidal patterns as the departure of packet ships; by the seasons of indigenous Indian Ocean traders as the constraints of factory life; and by a broader intermixture of the familiar and the novel. The experience of global travel demanded not only the carrying of existing conceptions and practices of time, but integrating with and accommodating these wider intersections. Success and survival meant, fundamentally, being capable of reading other timepieces.

It is within these contexts that we need to understand the Lawrence brothers' compulsion to (re)orient themselves not only spatially but temporally across the globe. In doing so, I situate time across numerous, co-existing registers: the aspirant precision of the Company's structures, but also the specificities of the local, the subjective, and the intimate. Locating time in this way demands a more comprehensive understanding of time's essential role in orienting and disorienting the global subject. In this sense, it answers Jyotsna Singh's call for a 'focus on tensions and contradictions' in the study of the East India Company's world, looking beyond the remit of the Company itself to encompass those whose lives intersected and clashed with it. ${ }^{25}$ In the first part of this article, I show that time for the Lawrence brothers was something to be 'invested' through the expectation and establishment of lucrative trade, but also in the retention of intimate contact across these vast spaces. This is constituted as 'intimate time'. In the second part, I situate these attempts at orientation within the wider temporal regimes noted above in order to highlight the tensions arising from Isaac Lawrence's mobile life, moving to considerations of 'Company time', 'indigenous time', and 'embodied time'. These are, in themselves, never wholly discreet in function: they overlap with and impact upon one another. However, it is precisely this overlap and interaction that I argue is central to comprehending their disorienting effects for the Lawrences. By moving beyond the question of precision and regulation in the service of nascent global capitalism and towards a focus on the subjective experience, I argue for an understanding of time that moves well beyond the watch.

\section{I}

The facts of Isaac Lawrence's life are unusually well documented compared to many of his contemporaries in the EIC. He died of dysentery in Isfahan on 10 August 1679 at the age of forty; this is known only because William later

\footnotetext{
${ }^{24}$ Compare with Kathleen DuVal, The native ground: Indians and colonists in the heart of the continent (Pittsburgh, PA, 2007), esp. ch. 2. See also Sebastian Prange, Monsoon Islam: trade and faith on the medieval Malabar Coast (Cambridge, 2018), esp. ch. 4.

${ }^{25}$ Jyotsna Singh, 'The local and global East India Company', JEMCS, 17 (2017), p. 125.
} 
gathered his brother's letters and memorialized Isaac's life 'that the memory of my dearly beloved Brother may remaine in my Family', not because of any attestation in surviving Company records. ${ }^{26}$ The subsequent collection around Isaac Lawrence's life therefore includes not only his original letters and letterbook (with copies of his outgoing correspondence), but also William's own narration of and reflections on his brother's life. Consequently, the family papers as William preserved them afford a particularly intimate glimpse into how Isaac's time in Asia was understood and narrated, both at the time and in the years following his death. While they can be read alongside Isaac Lawrence's presence in the East India Company's own records, they also offer an important site of discord and asynchronicity with them.

William was quick to draw together both the achievements and grim truths of Isaac's life cut short, finding solace in ordering his brother's time on earth in reassuring terms. The irony was not lost on William that Isaac had died on his birthday, noting the calendar day as 'being the Feast of St Laurence'. Of his brother's character, William wrote of time well invested in his having been 'bred a Merchant', as he 'was studious in Antiquity, did perfectly speak the Latin, French and Italian'. ${ }^{27}$ Looking back at the span of this mercantile career, William marvelled that Isaac had 'travel'd through many Countries, had liv'd long in Italy and view'd all the Coast and the port townes of the Mediterranean'. In Algiers, Isaac had been made a captive when Sir John Lawson's Mediterranean fleet attacked the city, only being released when peace was made 'to the dishonour of our Government'. Once again, adversity affords a theatre in which William sets out his brother's virtues: the 'Algerines' were so impressed by Isaac's 'temperance and justice' as to offer him the consulship at $£ 500$ per annum. Isaac, however, opted instead for Italy where cultivation - including an 'inspection into all the Curiosities' of Rome - combined with profitable trade in Livorno. ${ }^{28}$ What finally precipitated Isaac's departure for India, however, was not the 'curiosity' that had driven his time in the Mediterranean, but being 'at last tempted by the Treasures of India, which he sought not so much for himself, as that in the person of another he might revive the ancient Wealth and Honour of his Family.'. ${ }^{29}$ At least retrospectively, the spatial dimensions of Isaac's life made sense through these investments of personal and familial time.

These are, of course, the clarities and coherencies of retrospection on William's part, encouraged by sentiment and shaped by a clear sense of time lost in the wake of his brother's death abroad. Nevertheless, they already suggest a number of dominant temporal themes at play in Isaac's life: that he was 'bred a Merchant' and thereby bore a sort of destiny into his time in India; that his efforts were an investment not only in personal wealth, but the resuscitation of an 'ancient' family line; and, perhaps most remarkably, that his time in pursuit of profit in India through the East India Company was a markedly

\footnotetext{
${ }^{26}$ Lawrence, Diary, pp. 46, 64.

${ }^{27}$ Ibid., p. 46.

${ }^{28}$ Ibid., pp. 50-1.

${ }^{29}$ Ibid., p. 46.
} 
different 'type' of time than that which he had already spent in the Mediterranean. For the Lawrences, like many of their contemporaries, travel through the Mediterranean world was an investment of time for both the acquisition of material wealth and for self-cultivation. ${ }^{30}$ The Levant merchant Robert Bargrave, for instance, who travelled through the eastern Mediterranean in the decade before Lawrence, saw in these regions not just the 'tyranny' of the Ottomans as was commonly understood in England, but also the vestiges of early Christianity and Greek culture. ${ }^{31}$ Decades later, the Scottish merchant Henry Clerk could seize on opportunities in the eastern Mediterranean to find, buy, or steal pieces of Solomon's house in the wilderness, Sodom and Gomorrah ('burnt'), the Holy Sepulchre, and other marvels to send home to his staunchly Presbyterian father. ${ }^{32}$ This was time devoted to the pursuit of profit, but also time which facilitated the bettering of oneself, even in hostile spaces.

Isaac Lawrence's surviving letters confirm this overlapping of time and space in differing registers of profit and investment, with his departure from the Mediterranean trade into the Indian Ocean world driven first and foremost by personal and familial gain. Shortly after his departure for India, he wrote to a friend in London, the merchant William Bowtell, that he had already been 'fool'd into India in hopes of riches'. ${ }^{33}$ The brothers were in agreement, however, that the prospective riches were to the benefit of the family: William wrote to their uncle that 'Between curiosity and commerce my brother hath parted with much time and treasure...the maine reason which tempts him to search after the treasures of the East, is...[to] raise your family to its ancient splendour. ${ }^{34}$ Here, again, the brothers echo one another in their sense of the 'treasures of the East', with time spoken of not only as an investment but a gamble to be 'hazard[ed]' to restore the family's lost stature. ${ }^{35}$ In later letters written to William from India, Isaac expressed regret that his being in India prevented him from touring his young nephew around his 'beloved Italy. ${ }^{36}$ This was a resolute shift between the two spaces of Isaac's mercantile operation, venturing greater remove and personal danger for the promise of a more profitable investment of time. As would prove to be the trend, the

\footnotetext{
${ }^{30}$ Rosemary Sweet, The Grand Tour: the British in Italy, c. 1690-1820 (Cambridge, 2012).

${ }^{31}$ Michael G. Brennan, ed., The travel diary of Robert Bargrave Levant merchant, 1647-1656 (London, 1999).

${ }^{32}$ Henry Clerk to John Clerk, 21 Oct. 1699, National Records of Scotland, GD18/5218 (Clerk papers), fo. 16.

${ }^{33}$ IL to Bowtell, 30 Nov. 1677, IOR, LP, vol. A, fo. 25r. Bowtell was connected to the Mediterranean trade and later submitted reports about captives in Algiers: see Nabil Matar, British captives from the Mediterranean to the Atlantic, 1563-1760 (Leiden, 2014), pp. 125-6.

${ }^{34} \mathrm{WL}$ to 'Uncle William Lawrence Esqr', '1679', IOR, LP, vol. C, fos. 40-1.

${ }^{35}$ The family traced its lineage back to the twelfth-century Sir Robert Lawrence of Lancashire, though G. E. Aylmer has called this into question. See Iona Sinclair, ed., The pyramid and the urn: the life in letters of a Restoration squire: William Lawrence of Shurdington, 1636-1697 (Stroud, 1994); Lawrence, Diary, pp. ix-xiii.

${ }^{36}$ IL to WL, 18 Jan. 1677/8, IOR, LP, vol. A, fo. 33r.
} 
value of time would be inextricably connected with the space in which it was invested.

Preparing for departure meant preparing for time apart and the loss of intimate time. Many of Isaac Lawrence's contemporaries in the East India Company were so aware of the threats posed by this journey that they had new wills drawn up against the realistic prospect of their death abroad. In December 1676, for instance, Thomas Andrewes of London, despite being in 'health of body and of sound and perfect mind and memory' nevertheless wrote of the 'certainty of death' and the 'uncertainty of the time manner place and hower thereof and espeatially [sic] for that I am now bound forth on a voyage to parts beyond the seas'. Beyond leaving the majority of his estate to his wife, Susanna, he also stipulated various moneys to his wider family and friends so that they could buy rings 'to weare in Remembrance of me' ${ }^{37}$ John Gibbs, outbound for Persia in 1681 as an EIC servant, left his estates to his wife Sara but further stipulated the handing down of his estates in the event of her own death and that of their children, to the end that his nephew, Joseph Grove, 'now in Barbados', would inherit. ${ }^{38}$ Such plans required not only reckoning with the passage of time abroad and the unpredictable moment of death in the style of most early modern wills, but also preparing for the asynchronous march of time between the moment of death abroad, notification at home, and acts of remembrance. While, as David Veevers has argued, these distances could bind some families together as part of 'familial globalization', the fact remained that such distances forced new comprehensions of time lost and out of place. ${ }^{39}$

In the face of such anxieties about time lost, the Lawrence brothers made preparations to ensure longevity, stability, and enduring emotional connection. Isaac wrote, for instance, of having left William and their sister Jane with a pair of keys to a 'wainscott box with two locks on it' protecting his 'old papers'. This was to be opened 'upon the first newes of my Death' in order to set straight family affairs. ${ }^{40}$ Departure also meant ensuring that his material goods from his trade in the Mediterranean were returned home. The few surviving letters from the period before Isaac's departure for India revolve around a long-standing dispute over his possessions in Livorno: in particular, his collection of antique medals, intended for William's safekeeping but sequestered in the Livorno home of fellow merchant Slaughter Lee. ${ }^{41}$ These medals were a point of pride and symbol of cultivation for Isaac, described to fellow merchants in Livorno as 'very choice Antiquityes' and accompanied by Latin and Italian books documenting their history. ${ }^{42}$ Their study and

\footnotetext{
${ }^{37}$ Will of Thomas Andrewes, 21 Dec. 1676, The National Archives (England) (TNA), PROB 11/358/ 186.

${ }^{38}$ Will of John Gibbs, 1681, TNA, PROB 11/374/564.

${ }^{39}$ David Veevers, "'Inhabitants of the universe": global families, kinship networks, and the formation of the early modern colonial state in Asia', Journal of Global History, 10 (2015), p. 105.

${ }^{40}$ IL to WL, 18 Jan. 1677/8, IOR, LP, vol. A, fo. 32r.

${ }^{41}$ Stefano Villani, 'I console della nazione inglese a Livorno tra il 1665 e il 1673: Joseph Kent, Thomas Clutterbuck e Ephraim Skinner', Nuovo Studi Livornesi (2004), pp. 11-34.

42 'Mr Humphrey \& David Sidney', 'Adj[usted Calendar]', 16 Sept. 1672, IOR, LP, vol. A, fo. 1 r.
} 
understanding - a common appreciation of their physical embodiment of the past - became a means by which William could 'remember [Isaac] in his long design'd absence'. Even after Isaac's departure, William continued the pursuit of the full collection from Livorno merchants, writing that he had not only found himself eager to 'unriddle all their historical secrets' but finding solace in Isaac's 'little favourites of his fancy'. ${ }^{43}$ Sentimental and historical value intertwined through such objects; common fascination with historical time offsetting the loss of intimate time.

Only in these circumstances can we understand the reasons behind William's writing of his 'diary' and the aforementioned 'clock' which gauged the time surrounding his brother's absence. The diary represents not only a method of documenting time, but also projecting it across space in the hope that a structured, calendrical recounting of the year at home would ease Isaac's 'melancholy', anchoring days and months in fondly remembered settings and employing time itself as a salve. Indeed, William frequently wrote the diary entries anticipating where Isaac then was in his travels, and how the diary might find him. In July, for instance, William wrote that 'I now receive a letter from you dated at the Island of St Iago'-present-day Santiago in Cape Verde. In October, when William expected Isaac to have completed the voyage, he hoped his brother would 'take as much pleasure in the perusing as I had in the penning' of the letter. ${ }^{44}$ While time elapses in William's narrative in sequences and familiar geographies-'And now', 'About this time' or 'I am now got to Bednal Green' - it is written as a reflection on time itself and its capacity to reorient its reader and writer; to simultaneously mark time's passage, to suspend it, and to synchronize in the face of desynchronization. ${ }^{45}$ Whether this diary, in itself, reached Isaac is uncertain. It may have been one of a number of similar letters which William sent in Isaac's absence: in 1677, Isaac wrote from Fort St George that he had 'laughed very heartily at the ingenuity of y[ou]r last yeares annall', calling it 'a present'. ${ }^{46}$ Still, the purpose of William's interventions remains clear, with Isaac finding distraction and joy in these reminders of time's passage at home and a sense of synchronicity with his brother amid the wider disruptions which were to characterize his time in Asia. It is in this context that we must understand the varying experiences of time to which Isaac Lawrence remained connected on his departure for India, and the 'clocks' by which both his and William's relationship remained set as Isaac entered into the service of the East India Company.

\footnotetext{
${ }^{43}$ WL to Mr Humphrey Sidney, 'At Leghorne', 10 Apr. 1676, IOR, LP, vol. C, fo. 32r.

${ }^{44}$ Lawrence, Diary, pp. 22, 34.

${ }^{45}$ Ibid., p. 28; for comparable use of diary/daily writing, see Arianne Baggerman and Rudolf Dekker, 'Otto's horloge: verlichting, deugd en tijd in de achttiende eeuw', Tijdschrift voor Sociale Geschiedenis, 26 (2000), pp. 1-24.

${ }^{46}$ IL to WL, 30 Nov. 1677, IOR, LP, vol. A, fo. 23v.
} 
By 1673, then, Isaac Lawrence effectively entered the trading world of the East India Company. The cohesion and stability of this 'world' was something which the Company struggled to prop up from the outset of the voyage. By the latter half of the seventeenth century, travel around the Cape of Good Hope, while not 'routine' in the sense of being reliable or without risk, was nevertheless sufficiently familiar to sailors and merchants travelling eastwards that regularization and precise timing had become a greater institutional concern for the East India Company. From the moment of departure through the conduct of trade and the return of people and goods, the management of time was an investment, with risk read broadly across the spectrum of natural cycles (such as seasons and weather events), human error, hierarchies of power, and the terms of cultural encounter. Navigation, for instance, was increasingly the preserve of mathematical precision, building on a nautical book trade in which the Dutch had excelled and which the British emulated, but also a more formalized education system that favoured maths over astronomy. ${ }^{47}$ This desire for certainty and precision can be seen in the notebooks of Isaac Lawrence's contemporary, James Houblon. Son of a French Huguenot émigré and merchant, Houblon travelled to India (probably as an interloper) in the early 1680s, having invested in the Company and sat on its committees; he was also a trusted friend of Samuel Pepys, for whom he translated Dutch navigational books. ${ }^{48}$ His notebook suggests a telling intelligence-gathering exercise. Citing conversations with experienced sailors, he details distances between Indian Ocean ports in terms of precise (and optimal) times of passage: 'from Cape Bon Esperance from ye 25 May ships have gott into Bengall in 7 weekes \& 3 days; \& from sd 25 May to ye $17^{\text {th }}$ June have run 1000 Leagues wch is about $43 \frac{1 / 2}{2}$ leagues 1 day wth another'. ${ }^{49}$ Houblon's notebook elides time, profit, and space through such observations. He notes trading rates for currencies in Persia, Indonesia, and the coastal cities of India, followed closely by the regular course of winds and the rhythms of monsoons in the Indian Ocean, all with the aim of describing occurrences 'all ye year round $\mathrm{w}^{\text {th }}$ out variation'. ${ }^{50}$ In doing so, Houblon was emblematic of an East India Company venture which was not only familiar with the routes and methods of trade, but increasingly concerned with the measuring, regularizing, and systematizing of the times and distances which comprised them.

This increase in the methodical valuation of elapsed time for the sake of efficiency became enshrined in other archiving practices within and across the Company. Sea journals documenting dates of departure, weather patterns encountered, dates arrived in particular ports, as well as mortalities and injuries along the way, were returned to the Company archive in London as

\footnotetext{
${ }^{47}$ Margaret E. Schotte, Sailing school: navigating science and skill, 1550-1800 (Baltimore, MD, 2019), pp. 93-115.

${ }^{48}$ Houblon to Pepys, 'giveing an acct of ye Dutch Book of Navale Architecture', 18 Oct. 1679, Bodleian Library Rawlinson MSS A 173, fo. 13v. Houblon here translates Nicholaes Witsen's Aeloude en Hedendaegsche Scheepsbouw en Bestier (Amsterdam, 1671).

${ }^{49}$ Sir James Houblon's notebook, Huntington Library (HL) MS83394, fo. 8r.

50 Ibid., fos. $1 \mathrm{r}-11 \mathrm{v}$.
} 
reference points to encourage efficiency and minimize loss. ${ }^{51}$ Such regulation also became an increasing concern in the factories (or trading posts) the Company established: as Miles Ogborn has shown, from the mid-1670s the Company commissioned agents like Streynsham Master to travel to Fort St George (the administrative centre of Company activity) to help 'regulat[e] and methodise [sic]' the factories. This included reforms such as strict nine o'clock curfews, regimented dining, regular chapel attendance, as well as the institution of daily consultation books which documented how each day was spent. These were to be sent annually to London for scrutiny. ${ }^{52}$ Failure to adhere to these new temporal rhythms brought further examination. When, for instance, Major William Puckle audited the conduct of the factory in Machilipatnam in the mid-1670s, he was swift to comment on the regulation of the day - drinking after nine o'clock in the evening, the breaking of curfew, or the spending of time 'idly' by agents there - and record misdemeanours. ${ }^{53}$ This gave the lustre of precise 'merchant time' to the Company's operations that, if not always followed 'in the proper way and at the proper time' as desired, nevertheless suggested an institutional drive towards minimizing the loss of time and, with it, profit. ${ }^{54}$

A desire to regularize and control should not, however, be confused with the actual accomplishment of it; rather, the impulse to record is, as Stoler has argued, symptomatic of wider anxieties 'riveted on those affective states of European colonials...on those not within the state's reach to manage or assess ${ }^{55}{ }^{55}$ The temporal terms of cultural encounter were, from the early stages of the Company's trade in the Indian Ocean world, more often set (at least in the earliest iterations) by those with whom the Company sought to trade than by the Company itself. Among the richest sources for these early stages is Sir Thomas Roe's account of his embassy to the Mughal court from 1615 to 1619 on behalf of King James I and the EIC. Structured as daily entries from the day of his departure from England, the diary is punctuated by references not only to individual days, but also activities undertaken at different times in the day, effecting a sort of regularity and self-discipline in the face of the unfamiliar. Where encounter with representatives of the Mughal court intrude on the narrative, it is set to the rhythms of the narrator and often in a tone of resentment over time disrupted, lost, or beyond their control. For instance, the end of Ramadan in October 1615 and an ensuing feast at the court elicited annoyance on Roe's part for the spontaneous changes in his schedule: he was 'no baby, to be abused one day and pleased with a Pageant the next'. ${ }^{56}$ Tensions around time would only deepen as the Company and those within it aspired to greater precision and control - what Stuart Sherman has called 'collat[ing] the data of

\footnotetext{
${ }^{51}$ Glennie and Thrift, Shaping the day, ch. 8.

${ }^{52}$ Miles Ogborn, 'Streynsham Master's office: accounting for collectivity, order and authority in 17th century India', Cultural Geographies, 13 (2006), pp. 128-35.

53 'Diary of William Puckle', IOR/G/26/12.

${ }^{54}$ Ogborn, 'Streynsham Master's office', p. 136.

${ }^{55}$ Stoler, Along the archival grain, p. 41.

${ }^{56}$ Sir Thomas Roe, The embassy of Sir Thomas Roe, ed. William Foster (2 vols., London, 1899), I, pp. $72-3$.
} 
exotic space with that of familiar time,.$^{57}$ The consultation books which were meant to become Streynsham Master's great intervention in the ordering of Company time can also be read as a key site of tension in this regard. For instance, an entry for the Company factory at Cuddalore records the frustration felt by chiefs John Davis and Ralph Ord:

Sunday 13 [May 1683] - Yesterday haveing by message sent to ye Subidar that we intended to come and give him a visit, he returned answer that was one of their bad [i.e. inauspicious] dayes, and desired us to put it off, to this day, wch we desired him to excuse, ordering him to be acquainted that it was our Sabath and that we could not then discourse any thing of business, but he haveing at 5 a clock in the afternoon sent a message to us, that it was then a good hour expecting us to come, we thought if we should not goe, he might put us off with his delays and bad hours, we accordingly went at 7 a clock. ${ }^{58}$

Such entries suggest that, even beyond initial periods of 'encounter', tensions persisted over the differing practices and perceptions of time by which the Company and its hosts and competitors operated: differing rhythms of worship, ceremony, and reception ran alongside the timings of trade, diplomacy, and the conduct of 'business'.

Characterizing these indigenous temporalities as purely a source of tension risks a sense of inevitable contest over European 'precision' and its imposition in foreign contexts. Such a reading, however, ignores not only the multidirectional dialogue (and varied power dynamics) of early encounter, but also the practical adaptations needed to reconcile indigenous time with the rhythms of the wider environment. Attempts to acquire European timepieces were not uncommon in Asia. For instance, under Shah Abbas I (1579-1629), an Englishman named 'Fessy' made one of the first mechanical clocks in Isfahan (he apparently died in a revenge killing after he murdered a man in a brawl). However, the introduction or imposition of mechanical time usually gave way to older practices and seasonal rhythms. In Persia, the Muslim call to prayer continued to segment the day while the Zoroastrian festival calendar maintained influence throughout the period. ${ }^{59}$ Seasonal patterns of labour and mobility altered the feasibility of trade. Merchants would move northward into the cooler mountainous regions (sardsir in Persian) to escape the hotter months and then into the plains in cooler months (garmsir). ${ }^{60}$ In India, the Mughal Empire in the subcontinent likewise blended the Islamic calendar used by the ruling elite with some thirty or so Indic calendars, which established auspicious and inauspicious times and dates for trade. ${ }^{61}$ Seasonal shifts

\footnotetext{
${ }^{57}$ Sherman, Telling time, p. 169.

${ }^{58}$ IOR/G/14/1, fo. 13. For Roe, see Nandini Das, Sir Thomas Roe: eyewitness to a changing world (London, 2018).

${ }^{59}$ Stephen P. Blake, Time in early modern Islam: calendar, ceremony, and chronology in the Safavid, Mughal, and Ottoman Empires (Cambridge, 2013), p. 51.

${ }^{60}$ Ibid., ch. 2, passim.

${ }^{61}$ Ibid., pp. 29-37.
} 
often dictated working patterns, especially among local labourers upon whom the Company ultimately relied: in Cuddalore, the women who dyed many of the textiles on which the Company traded would not work in extreme heat, setting the rhythms of their work day within sustainable times of the day. ${ }^{62}$ James Houblon's observations detailed these seasonal patterns, connecting the intensity and frequency of the monsoons to patterns of trade and travel:

ye time ships go out from Surratt is com[m]only in Aprill seldome sooner for Syam Manilla Bantam or any where in ye South sea as likewise to Acheen Bengall Bussorah \& Persia, to ye last of wch places they com[m] only make two voyages going from Surratt in $9 \mathrm{r}$ or so soone as ye So [uth] W[es]t Monsoon is over likewise downe ye coast of India they com $[\mathrm{m}]$ only make two voyages wth provision as rice \&ca. ${ }^{63}$

As Houblon's notes suggest, the Company's gaze tended to fall on the profitably regular and the unprofitably disruptive. Catastrophic events such as an 'inundation' at Machilipatnam on 13 October 1679, which swept away 15,000 residents and destroyed the Dutch factory there, also warranted thorough documentation by Company observers both for the human and material cost. A report provided afterwards went so far as to time the event precisely between 10 o'clock at night and 4 o'clock the next morning. ${ }^{64}$ As Sunil Amrith has recently noted, the climatic shift of the Little Ice Age brought particular turbulence to regions such as the Bay of Bengal in the early modern period, fundamentally shaping the 'commercial system and diplomatic ambition' while 'upset[ting] the prevailing political order'. ${ }^{65}$

The Company's tenuous grasp on its own time can be seen from the beginning of Isaac Lawrence's outbound voyage to India, wherein his and the EIC's plans were immediately disrupted by the entanglements of the Atlantic Ocean. ${ }^{66}$ Lawrence left England without the Company's consent, trusting instead - as his brother later noted - in 'some very intimate Friends in the East Indies' who might facilitate a position there within the Company's trade. These were among the most influential figures in the Company at the time and active reformers in the administration of its affairs in Asia, including Gerald Aungier (president of the Company's factory in Surat and, from 1669, governor of Bombay), Walter Clavell (factory chief in the Bay of Bengal, whom Lawrence claimed to have freed from Algerian slavery), and

${ }^{62} \mathrm{IOR} / \mathrm{G} / 14 / 1$, fos. $209-10$.

${ }^{63}$ HL MS83394, passim.

64 'A narrative of an inundation...', IOR/E/3/40, fo. 150.

${ }^{65}$ Sunil Amrith, Crossing the Bay of Bengal: the furies of nature and the fortunes of migrants (London, 2013), pp. 49-51.

${ }^{66}$ On Atlantic 'entanglement', see 'AHR forum: entangled empires in the Atlantic world', American Historical Review, 112 (2007), pp. 710-99. The Atlantic as a discrete category is rightly questioned in Philip J. Stern, 'British Asia and British Atlantic: comparisons and connections', William and Mary Quarterly, 63 (2006), pp. 693-712. 
Streynsham Master himself. ${ }^{67}$ Betting on these connections, Lawrence set out as part of a fleet under Captain Richard Munden which accompanied East India Company ships to St Helena in the southern Atlantic Ocean. The timing here, too, was unfortunate, as St Helena had - 'though unknown here [in England]' according to William Lawrence - been seized by the Dutch in December 1672 . Through the help of an enslaved man named 'Black Oliver' (later freed for his efforts), Munden's fleet recaptured the island and returned to England in triumph. ${ }^{68}$ Lawrence found himself $£ 500$ richer through plunder at St Helena and, by 1676 , had sufficiently endeared himself to the East India Company that he was granted 'free liberty to trade in their Indies' on a bond not to trade 'in pearl and Diamonds'. ${ }^{69}$ At a time when Company concern about 'interlopers' that is, English subjects trading in Asia without Company licence - was pervasive, these disruptions to the Company schedule by broader Atlantic movements led to legitimacy for Lawrence's trade; it also, in William's reading of the events, reiterated his brother's 'designe for India' where he might otherwise have pursued 'considerable and less hazardous Imployments'. ${ }^{70}$

Isaac's arrival in India in 1677 quickly made clear another pervasive issue in the Company's temporal functions: the health and lifespan of its servants. ${ }^{71}$ Servants were ideally able to both enact Company will but also persevere over sufficiently long periods to act as reliable agents at a distance and in the face of lengthy delays in correspondence. As such, 'Company time' resided in the bodies of those conducting trade on its behalf. Lawrence - in his late thirties at the time of his arrival in India - noted that the Company had previously voted to send 'none but youths', with (in his estimation) only 'one in forty returned to their Native Soyle..$^{72}$ Precise mortality rates among East India Company servants - much less their wider families, households, servants, and chattel slaves - are evasive; however, records certainly suggest a pervasive awareness of demands on the body and fears of death. ${ }^{73}$ Few reached the age of Andrew Gill, who was brought before the council in Machilipatnam in 1675 for running a 'punch house' without licence, describing himself as 'ab[ou]t 70 years of age past labour unable to returne for England' after fifteen years resident there. ${ }^{74}$ Women - often little more than a perceived threat to order in Company records - were occasionally employed in its service in the hope of improving and extending the livelihoods of its servants in Asia. In the same year Lawrence arrived in India, for instance, a court of committees in

\footnotetext{
${ }^{67}$ Ogborn, Indian ink, ch. 3; for Aungier, see Philip J. Stern, The company-state (Oxford, 2011), pp. 26-8; Lawrence, Diary, p. 54.

${ }^{68}$ Stephen Royle, 'Island history, not the history of islands: the case of St Helena', Shima, 13 (2019), p. 50.

${ }^{69}$ Lawrence, Diary, p. 54.

${ }^{70}$ Ibid., p. 54; Stern, Company-state, pp. 45-6.

${ }^{71}$ Cheryl Fury, 'The impact of physical, spiritual \& mental health on shipboard order in the early English East India Company voyages, 1601-1611', Hakluyt Society Annual Lecture Series (2018), pp. 1-25.

${ }^{72}$ IL to WL, 30 Nov. 1677, IOR, LP, vol. A, fo. 23v.

${ }^{73}$ The first fleet saw an estimated mortality rate of 60 per cent. See Fury, 'Shipboard order', p. 1.

74 'Diary of William Puckle', 26 Oct. 1675, IOR/G/26/12.
} 
London ordered that twenty-five young, unmarried women be permitted travel to India free of charge - five to Fort St George, the rest to Bombay - with 'certificates of their behaviour' so that they would be 'fitt to make wives'. This, it was thought, would encourage the growth of families and a more fixed physical presence for the Company in India. ${ }^{75}$ Yet, prolonging life 'on the ground' in the Company's factories and ships was often an exercise in improvisation, working with bodily rhythms and limitations rarely understood or considered in Britain but at the centre of colonial and mercantile expansion since the early sixteenth century. ${ }^{76}$ The factory at Cuddalore, for instance, became so desperate for medicines that in 1683 they wrote to Fort St George threatening that they would 'be forced to make use of the Dutch doctor' at the neighbouring VOC factory. ${ }^{77}$ Amid frequent reports of deaths or malnutrition in transit and the rapid collapse of health on arrival, observers such as Houblon took note of the foods which could sustain and preserve lives over such time. His recommendations for food in transit included coffee and chocolate (both recent additions to the English palate), but also pilau rice; he noted that salted provisions were unwise for hot climates and local chintz cloth coats best for surviving the heat. ${ }^{78}$ Yet, the lifespan of Company servants remained morbidly linked to questions of climate and age in their imaginations: so much so that the chaplain John Ovington claimed 'Two Mussouns [Monsoons] are the age of man' had become a common proverb in Bombay by the end of the seventeenth century. ${ }^{79}$ In such instances, the consumption of the right foods not only sustained the body of the working Company servant, but extended the time in which they remained profitable at such distances.

For all such planning and the prospect of prolonging lifespans abroad, Isaac Lawrence's first descriptions of time in India were that of a 'fatal year', laid waste by the sudden death of his contact in India, Walter Clavell. Isaac wrote to a friend in London of having travelled up to Balasore (Baleshwar) from Fort St George

where I had the happyness to see my Friend, but in a short time after saw not only him, his Lady, the Cheife of Balasore, \& almost [their] whole ffactory there lay'd in their untimely graves, my selfe narrowly escaping after a desperate \& tedious sicknes[s], the distemper pestilentiall feavers generated by a corrupt Aire. ${ }^{80}$

The 'corrupt air' had been a long-standing trope of European commentary on many Indian Ocean climates; in this instance, though, the absence felt by Lawrence and subsequently related back to both his brother and many contacts

\footnotetext{
75 'Court of committees, 7 November 1677', in Ethel Bruce Sainsbury, ed., A calendar of the court minutes etc. of the East India Company, 1677-1679 (Oxford, 1938), p. 107.

${ }^{76}$ Rebecca Earle, The body of the conquistador: food, race and the colonial experience in Spanish America, 1492-1700 (Cambridge, 2012), esp. ch. 2.

77 Davis and Ord to Fort St George, 15 Nov. 1683, IOR/G/14/1, fo. 268.

${ }^{78}$ HL MS83394, fo. $18 \mathrm{v}$.

${ }^{79}$ John Ovington, A voyage to Suratt (London, 1696), p. 142.

${ }^{80}$ IL to Edward Rudge, 18 Jan. 1677/8, IOR, LP, vol. A, fo. 38.
} 
in England was of wastage and 'untimely' loss of life. ${ }^{81}$ Lawrence's fortunes deteriorated again when news later reached him that Gerald Aungier had died in Surat, leaving Lawrence without vital contacts in the Company. ${ }^{82}$ Hoping to prolong his own time in India, he wrote to his brother for medicines - variously for 'grippings, looseness, bloody fluxes' - having 'lately seen' a copy of William Walwyn's Physic for families of 1669. He asked that William find Walwyn in London to procure what was thought necessary for 'the usuall distempers of these Countryes'. Such requests emerged out of a professed 'unwillingness to dye [sic]'. ${ }^{33}$ Yet, even when Company work later became available and required his move to 'Gombroon' (Bandar Abbas) in Persia, reminders of his mortality continued to intrude on his time. While he found the chief of the factory 'in very good health, growing fatt', he regretted the 'unkind season yt draws near' and the oppressive heat, both of which threatened to diminish not only his trade prospects but also his health. ${ }^{84}$ Letters written from Bandar Abbas suggest futile attempts to rely upon 'Bannian's medicine' (that is, those of an Indian merchant named Moradas Parrack whom he had befriended in Surat and with whom he now corresponded, including in Parrack's 'Bannian character'). ${ }^{85}$ Nevertheless, Lawrence's health remained so poor that he was desperate to travel to Isfahan in the hopes that the air would improve. ${ }^{86}$ We know through his brother's later account that such hopes were soon dashed.

The constant instability and unreliability of Lawrence's body also prompted thoughts of how best to use what time he had left in the world. Where the spectre of death was never far from EIC factories, its proximity could provoke changes of heart. Wills written as death loomed are not uncommon among Lawrence's contemporaries, either in India or Persia: Thomas Best, for instance, drafted a new will in Isfahan in 1651, being of 'reasonable health' but unsure of the 'place or time' of death, leaving goods to family in England but also money to his eleven servants (one alone named as 'Mahmut'). Best died two years later. ${ }^{87}$ The immediate effect of the brush with plague in Balasore, however, was that Lawrence saw this as a timely repentance', giving him pause to see a 'great change in all my morals' and a reassessment of how he spent his time. By the end of 1677, Lawrence was

\footnotetext{
${ }^{81}$ Mark Harrison, Climates and constitutions: health, race, environment and British imperialism in India 1600-1850 (Oxford, 1999), ch. 1; Leonard Blussé, Strange company: Chinese settlers, mestizo women and the Dutch in VOC Batavia (Dordrecht, 1986), pp. 29-30.

${ }^{82}$ IL to William Bowtell, 30 Nov. 1677, IOR, LP, vol. A, fo. $25 \mathrm{v}$.

${ }^{83} \mathrm{IL}$ to WL, 30 Nov. 1677 , IOR, LP, vol. A, fo. $24 \mathrm{v}$.

${ }^{84}$ IL to Thomas Rolt, 8 Apr. 1679, IOR, LP, vol. A, fo. 86r. For Bandar Abbas and EIC trade in Persia more generally, see Peter Good, The East India Company in Persia: trade and cultural exchange in the eighteenth century (forthcoming), ch. 5.

${ }^{85}$ The 'Bannian character' mentioned is probably Sanskrit or Gujarati given Lawrence's travels. Parrack's son is later described by Lawrence as 'a very honest young man considering the Cast', suggesting that Parrack was not of the high social status normally associated with brahmin intermediaries: see IL to Hibbins, 25 Apr. 1679, IOR, LP, vol. A, fo. 92r; Winterbottom, Hybrid knowledge, ch. 4.

${ }^{86}$ IL to Hibbins, 8 Apr. 1679, IOR, LP, vol. A, fo. 87r; IL to Parrack, 25 Apr. 1679, IOR, LP, vol. A, fo. 90r.

${ }^{87}$ IL to WL, 30 Nov. 1677, IOR, LP, vol. A, fo. $24 \mathrm{v}$.
} 
already writing home to merchant friends in London of his profound disappointment in the opportunities provided by trade in India, and was even then trying to seek advice from friends abroad that I loose [sic] not a yeares time ${ }^{88}$ This sense of losing time pervades many of his subsequent letters in India - phrases such as 'loss of time \& health' are commonly used to describe his apprehensions. ${ }^{89}$ Where they overlapped with returning post from these friends, the monotony of the situation was reiterated: he wrote to a merchant named Edward Rudge in London that, while he was able to send a quilt Rudge had requested in the previous year's post, he continued to have 'nothing but disappointments' in India, and had 'idled away two yeares time in expectation of what these $\mathrm{p}$ [ar]ts affoard not'. ${ }^{90}$ Delayed in acquiring access to the Company trade he had hoped to attain through Clavell and Aungier, Lawrence's frustrations turned to the Company itself, which he (for now) condemned as a 'beggarly maintainance [sic] w:th meat \& drinke being the best of it', doubting whether he would take up the work even if his petitions were well received. ${ }^{91}$

Under these circumstances of disappointment and a pervasive sense of time wasted - 'lost years' - Lawrence's writings began to adopt a tone of tedium and anxiety as he grasped at passing opportunities to redeem time spent. ${ }^{92}$ Letters sent to England instead increasingly focused on what was seen, acquired, and experienced in the wake of unprofitable time and those things that could afford an enduring connection with his brother. Within weeks of his arrival in India, Isaac was already arranging for gifts to be sent home to William: among them, a 'hubble-bubble' (a hookah pipe) from 'Racan' (Rakhine) which he suggested could be kept in William's private study; jewel boxes and Chinese porcelain; bezoar stones, rare Mughal coins, and unspecified 'rolls of pictures'. ${ }^{93}$ All of these were sent with expressed anticipation that they might be kept in the intimate spaces of William's home, providing 'ornament' for his brother's study. ${ }^{94}$ It is easy to imagine that such gifts offered Isaac an opportunity to think of the distant but familiar corners of Shurdington, affording a means of placing something of his life in William's everyday surroundings. Accompanying many of these objects were some of the few positive descriptions of Asia which Isaac could muster: Isaac noted the 'only thing of wonder' he had yet seen in India were the Elephanta Caves on Gharapuri and the carved stone temple of Salsette, both described as 'ye greatest part of Antiquity \& wonder that the World affords'. Alluringly, William also noted that a letter had been written by Isaac to the chief of Balasore not long before his death expressing hope that he would

\footnotetext{
${ }^{88}$ IL to Bowtell, 30 Nov. 1677, IOR, LP, vol. A, fo. $25 \mathrm{r}$.

${ }^{89}$ IL to Canham, 30 Nov. 1677, IOR, LP, vol. A, fo. $27 \mathrm{v}$.

${ }^{90}$ Will of Thomas Best, 8 Aug. 1651 (proved 9 Sept. 1653), TNA, PROB 11/29/600; IL to Rudge, 18 Jan. 1677/8, IOR, LP, vol. A, fo. 38.

${ }^{91}$ IL to WL, 18 Jan. 1677/8, IOR, LP, vol. A, fo. 32r.

${ }^{92}$ Observed in later periods in Jeffrey A. Auerbach, Imperial boredom: monotony and the British empire (Oxford, 2018).

93 'Postscript', 'Madras 30 Nov. 1677', IOR, LP, vol. A, fo. 31v; IL to WL, 18 Jan. 1677/8, IOR, LP, vol. A, fo. 32 r.

${ }^{94}$ IL to WL, 18 Jan. 1677/8, IOR, LP, vol. A, fo. 32r.
} 
write a longer study of the 'Kingdom of Bengala', including its 'Antiquities', and had written to 'several other Agents and Chiefs of Factories' to a similar effect. ${ }^{95}$ Isaac nevertheless claimed that the present-day population were ignorant of the value of such sites, with their meaning in time lost to their inheritors. ${ }^{96}$ Here, 'indigenous time' took an alternative form to the daily rhythms of trade, calendar, and ritual: the deeper histories of India and Persia offered value to be 'recovered' through European appreciation and acquisition, akin to the 'Antiquities' and medals of the Mediterranean over which the Lawrences had bonded but on a perceived blank slate awaiting European understanding. ${ }^{97}$

The opportunities provided by these interactions with the past nevertheless hinged predominantly on the temporalities of Indian Ocean and Asian trade. In September 1677, Isaac wrote to a friend in London asking him to 'acquaint my Brother with the times \& seasons of the shipping for these parts that I be not disappointed of his letters'. ${ }^{98}$ This proved prescient in both directions: letters between the brothers apparently went astray, and the receipt of gifts went unconfirmed as ships were lost or delayed in transit. The gifts themselves were usually the product of happenstance, brought by passing traders from China or along Persian trade routes. Indigenous merchants and intermediaries became the essential route by which such bonds were maintained. For instance, by the time Lawrence gained employment within the Company to take up trade in Bandar Abbas, he relied upon the skills and local knowledge of merchants like one 'Aga Doud', whom he asked to acquire 'a Couple Pictures' in 'Anticke pleasing Postures', preferring those of 'huntsmen', 'peasants or countrymen'. ${ }^{99}$ Chance encounters with such rarities that were not seized upon were regretted, as was the case when he passed on a Chinese screen encountered on his way to Bengal. Described as 'richly gilt full of such variety of excellent Landskipps [landscapes]', the screen was hailed by Lawrence as 'the greatest rarity I ever saw in my whole life'. ${ }^{100}$ It left enough of an impression that he spent months trying to find something comparable to send home. ${ }^{101}$ The occasion to see and relate unusual experiences hinged on Isaac's sense of where and how 'time' was situated in the landscapes in front of him, with 'ancient' history accorded value in opposition to an apparently valueless present. Still, where history had provided a bond between the brothers at such distances, engagement with it was still subject to the tides, seasons, and circulation of people and goods around and beyond the Indian Ocean. This remained the case however connected Isaac may have wished to be, and whatever regularity the East India Company might have aspired to provide.

\footnotetext{
95 Lawrence, Diary, p. 64; IL to Edwards, 14 June 1679, IOR/E/3/40, fos. 56-7.

${ }^{96}$ IL to Edwards, 14 June 1679, IOR/E/3/40, fos. 56-7.

${ }^{97}$ Maya Jasanoff, Edge of empire: lives, culture, and conquest in the east, 1750-1850 (New York, NY, 2005).

98 'Postscript to Bowtell', Madras, 30 Sept. 1677, IOR, LP, vol. A, fo. 31v.

99 IL to 'Sig[nor] Agga Douid [later referred to as Doud]', 14 Oct. 1678, IOR, LP, vol. A, fo. 64v.

${ }^{100}$ IL to WL, 30 Nov. 1677, IOR, LP, vol. A, fo. 23v.

101 'Postscript of my letter to Mr Robert Marshall', IOR, LP, vol. A, fo. 28r.
} 
In the days before his death, these many temporalities in Isaac's life coalesced in a particularly pointed way. Late in April 1679, Isaac Lawrence wrote one of his last surviving letters, this time to Charles James, the second-in-command at the Company factory in Surat. He described the circumstances of trade in Bandar Abbas in minute detail:

This country of late hath been afflicted with ye Dearths of Food \& Commerce; this yeare promiseth faire for a remedy to the former by ye great Raines fallen up in the Country wch will be the only meanes to recover the latter for the Belly being satisfyed the back will be the more regarded \& fare the better. ${ }^{102}$

This may well have been a speculative explanation of the dearth in trade at the time: Lawrence also went on to blame the heat of the season and the local brokers for the 'decay of the Traffick in this place'. ${ }^{103}$ Nevertheless, the fact remained that Lawrence continued to be acutely aware of the forces which now shaped his successes and failures in Persia, with trade not simply a matter of will or power, but also the wasting away of time as the combined factors of seasonal trade and indigenous practice prohibited profit. News of Europe passed briefly through his hands as old gazettes progressed onwards to Surat and the other Company factories. Still, he lamented that 'Europe Novelties' remained few and far between. Instead, Lawrence arrived at the conclusion that there was 'not living' to be had in Bandar Abbas if his attempts to make good on his time were to succeed, resolving instead to travel to Isfahan by the end of May, despite the 'intollerable heat'. ${ }^{104}$ In letters to companions, he reiterated his disappointment in the trade, maintaining that 'I hope "ere this time twelve month to quitt this place \& ye Companyes service, and so either for ye Bay, Surat, or home for England'. ${ }^{105}$

III

We know the how and where - the approximate time and place - of Isaac Lawrence's death in Isfahan; but the prospect of losing his brother had haunted William Lawrence for years prior to the final, grim moment of notification. In one instance, Isaac had apparently written to William in the 'dead of night and neare (as he thought) his expected death' that he would be losing 'the most loving of Brothers and the best of Friends'. ${ }^{106}$ The practicalities of longdistance communication meant that, when Isaac had recovered only a few days later and wrote reassuringly to his brother, both letters 'by God's great mercy and indulgence...came to [William's] hand at the same time'. William's response detailed a dream he claimed to have had the very night of Isaac's near-death: his own 'loud and bitter lamentations', he speculated, might

\footnotetext{
${ }^{102}$ IL to Charles James, '2d of Surat', 25 Apr. 1679, IOR, LP, vol. A, fo. 91v.

103 IL to Rolt, 26 Apr. 1679, IOR, LP, vol. A, fo. 93r.

${ }^{104}$ IL to Hibbins, 25 Apr. 1679, IOR, LP, vol. A, fo. 92r.

105 IL to Kelway, 17 June 1679, IOR, LP, vol. A, fo. 102r.

${ }^{106}$ Lawrence, Diary (IL to WL, 8 May 1678), pp. 54-5.
} 
have 'call'd [Isaac] to life again' that very night across thousands of miles. ${ }^{107}$ This dream was not a matter of 'Chance', but held to have been divine intervention as God alone could 'arrive at an immediate knowledge of such distant Actions'. ${ }^{108}$ In these moments, the pains of distance and the asynchronous terms of their relationship seemed to briefly lapse, achieving a sort of synchronization through divine favour.

Deaths in the family made the passage of time all the more acute in their correspondence: in 1679, William wrote to Isaac of the death of their father. These prompted something of a Shakespearean turn in William's reflections on time with his brother, writing that 'like ships we are rigg'd into the World for a few yeares...whirl'd about by windes,...or wasted by Time...either perplex't with different Affaires...or Decay by Age'. ${ }^{109}$ Threading together many of the temporalities which had governed their lives-the mobile, embodied, environmental, and above all disoriented experience of time - the letter ultimately proved prescient. On 23 January 1680 - 'in the morning' for William, but now long since Isaac's death - William received two letters from Isaac dated 23 and 30 May which had travelled via Aleppo. ${ }^{110}$ Both letters again presented a morbid simultaneity, pairing an initial report of Isaac's relapse into illness with the flux, only to then revise the situation noting his recovery and good health. Writing back to Isaac, William again drew on imagery of storms and fraught passage: 'my Soule will feele the many Stormes that you have pass't through and be toss't about by a dreadful Confusion'. ${ }^{111}$ William finished by expressing hopes that Isaac would achieve his aim of visiting the ruins of Persepolis; by this time, however, Isaac had been dead for nearly five months in Isfahan. News of Isaac's death, according to William, arrived on the same day as a picture of his brother which he had sent for from Italy: he described this as a "poor exchange, to receive a Shadow for such a substance. ${ }^{112}$ Once again, the awkward synchronicities of time in the brothers' relationship only amplified the sense of loss as mercantile endeavour collided with the harsh realities of distance and the mobile body of the merchant.

Such stalls and stoppages return us again to the Lawrence brothers' two timepieces with which I began this article. The aspirations which we might see embodied in Isaac Lawrence's watch were certainly present in his life and in the world through which he moved: an evident search for precision, consistency, and indeed a sense of place circumscribed by the ticking of familiar time which he shared with the wider EIC. The watch, however, affords only a glimpse at the multiplicity of time cultures in operation. In Lawrence's experience we see the constant intertwining of time and temporalization with the navigation of both new and familiar spaces. This became part of

\footnotetext{
107 Ibid., pp. 55-6.

108 Ibid., p. 56.

109 Ibid., p. 35.

${ }^{110}$ Ibid., pp. 57-8.

${ }^{111}$ Ibid., p. 58.

112 Ibid., p. 56.
} 
what historians increasingly recognize as the 'non-linear' dimension of English presence in Asia, shaping definitions of profit, investment, and the management of activity. ${ }^{113}$ Time in its many forms needs to be seen as a crucial site of tension in that story between the initial rhythms of cultural encounter and later efforts at time reform. ${ }^{114}$ This multiplicity of temporalities also brings to the fore dissonant voices to which historians of global mobility must pay close attention. Where the Company's own story spoke and continues to speak of efficiency, expansion, and profit, attention to differing rhythms allows us to hear experiences of frustration, loss, and failure. Here, vividly illustrated in cases like the Lawrence family, we find a constant gauging and reworking of time not just within the precise scales of monetary loss and gain, but in the deeply personal valuation of time across ever-changing landscapes.

These dissonant experiences of time also encourage us to move the study of time and temporalities in the early modern period both outward and inward: beyond the city walls and borders which lent time a fixed geography, but also into the intimate lives of those who kept it and felt its passage. Movement placed a constant demand on individuals to triangulate the rhythms and rituals of their lives within unfamiliar time cultures. The example of the Lawrences suggests this was an adaptive but difficult process, drawing on external reckonings of time's passage across physical and cultural boundaries while also struggling to inwardly reconcile them with what was familiar and valuable. It is in the variety of these temporal experiences and adaptations that we find the disorientations and reorientations that defined global movement. For these people, time was often part of the baggage that-like Isaac Lawrence's watch - could be brought along, damaged, repaired, reset, replaced, or lost in the course of their mobile lives.

\footnotetext{
${ }^{113}$ Veevers, Origins, p. 272.

114 Ogle, The global transformations of time.
}

Cite this article: Williams MRF (2022). Experiencing Time in the Early English East India Company. The Historical Journal 65, 1175-1196. https://doi.org/10.1017/S0018246X2100087X 